Dr NIKOLA MIJATOV, naučni saradnik

Institut za savremenu istoriju

Beograd, Republika Srbija

UDK 796.853.23:32(497.1)"198/199"(093.2)

nikolamijatov@gmail.com

352.08(497.1)"199"(093.2)

prethodno saopštenje / preliminary communication

primljeno / received: 21. 11. 2019.

prihvaćeno / accepted: 20. 5. 2020.

https://doi.org/10.29362/ist20veka.2020.2.mij.219-230

\title{
DŽUDO KLAN: ULOGA DŽUDOA U KARIJERAMA ISTAKNUTIH POLICIJSKIH FUNKCIONERA JUGOSLAVIJE
}

APSTRAKT: Članak razmatra karijere istaknutih policijskih funkcionera na prostoru Jugoslavije 90-ih godina 20. veka za koje je zajednička karakteristična crta bila bavljenje džudoom. Dinamika karijere Radomira Stojičića Badže, Sente Milenkovića, Gorana Radosavljevića Gurija i drugih analizirana je dominantno uz pomoć intervjua istaknutog funkcionera Džudo saveza Jugoslavije i njihovog bliskog prijatelja, Vuka Rašovića.

KLJUČNE REČI: džudo, džudo klan, Radovan Stojičić Badža, Senta Milenković, Goran Radosavljević Guri

Napredovanje u karijeri često zavisi od toga koga poznajete i koliko duboko. Opsežna istraživanja su ukazala na presudnu ulogu mreža poznanstava koja, primera radi, mogu datirati još iz britanskih školskih klupa (old boys network) ili iz američkih studentskih bratstava (npr. uticaj tajnog društva Skulls and Bones iz Jejla na formiranje CIA). U našoj sredini takve mreže i veze, osim po školskoj, formiraju se i na zavičajnim osnovama. ${ }^{1} \mathrm{U}$ socijalizmu su takva grupašenja bila vezana za pripadnost istoj partijskoj organizaciji (recimo fakultetskom partijskom komitetu), ili za druge osnove (zajedničko ratničko iskustvo, rad u istoj firmi). Naravno, uspeh je bio tim sigurniji što se osoba nalazila na preseku više takvih koloseka. ${ }^{2} \mathrm{U}$ određenim profesijama, međutim, postojali su i manje primetni načini koji su mogli lansirati osobu pravo na vrh.

\footnotetext{
${ }^{1}$ Više o neformalnim vezama u postsocijalističkom društvu u: Informal Power Networks, Political Patronage and Clientelism in Serbia and Kosovo*, edited by Slobodan Cvejić (Belgrade: SeConS, 2016).

${ }^{2}$ Neformalni načini političke promocije po svome značaju često prevazilaze formalne tokove karijernog napredovanja. Ono što njihova istraživanja otežava jeste brz prelaz iz neformalnosti u formalnost gde se promovisani pojedinci brzo uklope u zakonske okvire, kao i činjenica da iza neformalnih načina promocija najčešce ne ostaju pisani tragovi. Helmke Gretchen and Steven
} 
Ovaj članak se bavi jednim od tih načina, to jest ulogom koju je profesionalno bavljenje u oblasti borilačkih veština, a posebno džudo, igralo u karijerama policijskog kadra u poznom socijalizmu. Pratiće se karijera nekoliko policijskih kadrova poput Milana Kresoje, Momčila Mandića, Miće Stanišića, Josipa Lucića, Mladena Markača i drugih, koji su se tokom rata našli na suprotstavljenim stranama, premda su potekli sa iste strunjače. Posebna pažnja će biti posvećena isprepletenim karijerama Radovan Stojičića Badže, Sente Milenkovića i Gorana Radosavljevića Gurija, čija je povezanost podvučena džudom dosegla razmere istinskog klana. Sve njih trenirao je Vuk Rašović, majstor džudoa 9. dan, veteranski prvak sveta i direktor Džudo saveza Jugoslavije 90-ih godina. Rašovića je autor ekstenzivno intervjuisao. Uz taj izvor i uz ostale njegove intervjue iz štampe i periodiku MUP, pokušaćemo da ocrtamo njihov uspon u policijskoj hijerarhiji 90-ih godina i ulogu džudoa u tom usponu.

\section{Sa iste strunjače}

Pojedinci o kojima je reč potekli su ,sa iste strunjače“, odnosno pripadali su školi jugoslovenskog džudoa osnovanoj još 1951. godine otvaranjem prvog džudo kluba u Jugoslaviji, ,Mladost“ iz Zagreba. ${ }^{3}$ Ta škola je od svojih početaka bila u bliskoj vezi sa vojskom, a još bližoj sa policijom. Kao plod te saradnje izdvojio se niz kadrova koji su preko džudoa izgradili karijere i ostavili svoj pečat na istoriju jugoslovenskog džudoa, a preko njega i istoriju Jugoslavije.

$\mathrm{U}$ toku svog sportskog formiranja oni su se sretali i upoznavali kroz džudo. Uz pomoć pregleda svih prvenstava Jugoslavije u džudou možemo sagledati kada su se susretali na finalnim takmičenjima. U 1977. godini, kada je prvenstvo održano u Prištini, susreli su se Mladen Markač (3. mesto do $71 \mathrm{~kg}$ ), koji se takmičio za klub „Mladost“ iz Zagreba i Rajko Kušić (3. mesto do 95 kg), za klub „Bosna“ iz Sarajeva. Na sledećem prvenstvu, 1978. strunjaču su delili Hajlurah Trnava i Kušić. Sledeće godine Radovan Stojičić i Kušić. Za prvenstvo 1980. godine zanimljivo je da su Stojičić i Markač ne samo delili strunjaču već verovatno imali i međusobnu borbu budući da je u kategoriji do $78 \mathrm{~kg}$ prvo mesto osvojio Markač a treće Stojičić. Ako nije imao meč sa Markačem, Stojičić je sigurno imao meč sa Josipom Lucićem koji se borio u istoj kategoriji i izgubio od drugoplasiranog Marjana Fabijana. ${ }^{4}$ Dve godine kasnije Stojičić je bio bolji i u istoj kategoriju zauzeo drugo mesto, a Markač treće. Na istom takmičenju u kategoriji do 95 kg bio je i Kušić. Markač i Kušić bili su različita kategorija, ali su sigurno delili strunjaču i 1984. godine kada je Markač osvojio srebro a Kušić zlato. Sledeće, 1985. bilo je obrnuto: Kušić srebro, a

Levitsky, „Informal Institutions and Comparative Politics: A Research Agenda“, Perspectives on Politics, vol. 2, no. 4, (2004), 726.

${ }^{3}$ Stojan V. Nedeljković, Džudo u Jugoslaviji 1955-2005 (Beograd: Stojan Nedeljković, 2007), 11.

${ }^{4}$ Treba imati u vidu da je moguće da je Stojičić došao do 3. mesta repasažom koji bi pratio osvajača drugog mesta Fabijana. U tom slučaju on i Markač se nisu borili, ali su se sigurno borili Stojičić i Lucić budući da je Lucić izgubio od Fabijana. 
Markač zlato. ${ }^{5}$ Sasvim sigurno, susreta, treninga i borbi na strunjačama bilo je daleko više, ali i samo pregled osvajača prvenstva Jugoslavije pokazuje dinamiku susreta i zajednički sportski život koji su delili.

Sa iste strunjače potekao je i pojam „džudo klan“, koji se vezuje za ključne policijske funkcionere tokom 90-ih godina, kao i bliske saradnike Slobodana Miloševića: Radovan Stojičić Badža, Senta Milenković i Goran Radosavljević Guri najčešća su imena koja se spominju uz ovaj pojam. Međutim, nisu jedini: postojao je niz istaknutih džudista kako u Srbiji, tako i Hrvatskoj, Republici Srpskoj i na prostoru Kosova. Prvo, sagledaćemo biografije istaknutih jugoslovenskih džudista iz vrha jugoslovenske policije: Radovana Stojičića Badže, Sente Milenkovića i Gorana Radosavljevića Gurija. Potom, izložićemo i biografije drugih istaknutih džudista sa prostora Jugoslavije i ulogu džudoa u njihovim karijerama.

\section{Radovan Stojičić Badža}

Rašović je Stojičića primetio 1971. godine na juniorskom prvenstvu Jugoslavije na kome je Badža osvojio prvo mesto i iskazao džudo zavidnog nivoa. Sin rudara, trenirao je džudo od malena i potom upisao Srednju školu unutrašnjih poslova u Sremskoj Kamenici u kojoj se takođe istakao, opet preko džudoa. Aktivno je trenirao i tokom školovanja i dalje policijske karijere. Završio je Višu školu za fizičku kulturu i potom Fakultet za fizičku kulturu u Beogradu na kome je magistrirao 1995. godine. Postoje navodi da je 1983. završio i Višu pedagošku školu u Beogradu. Počeo je karijeru kao milicionar-pozornik SM Palilula. Istakao se 1973. godine prilikom posete japanske džudo delegacije u kojoj su bili Isao Inokuma ${ }^{6}$ i Jasihuro Jamašita. ${ }^{7}$ Stojičić je nastupio za ekipu Jugoslavije i odneo pobedu bacanjem, koje su primetili i ovi veliki japanski majstori. Istakao se i na Balkanskom šampionatu kada je osvojio bronzanu medalju Evrope i u finalu pružio dostojan otpor tadašnjem prvaku Balkana Georgiju Petrovu. Od značajnijih medalja, ističe se bronzana iz 1973. godine sa studentskog prvenstva sveta u Brazilu. Nosilac je crnog pojasa 6. dan. Njegovi džudo uspesi su bili primećeni u MUP-u Srbije i na osnovu njih postaje instruktor za borilačke veštine u Gradskom sekretarijatu za unutrašnje poslove u Beogradu. U svojoj 37. godini (1992), posle okončanja takmičarske karijere, istaknut je kao jedan od najuspešnijih sportista policije SR Jugoslavije. ${ }^{8}$

\footnotetext{
${ }^{5} \mathrm{~S}$. V. Nedeljković, $n$. d., 59-91.

${ }^{6}$ Inokuma je osvajač zlatne medalje sa Olimpijskih igara u Tokiju 1964. godine. Posle karijere vrhunskog sportiste džudoom nastavlja da se bavi kao savetnik u Svetskoj džudo federaciji. Bio je aktivan kao trener i jedan od učenika mu je bio Jasihuro Jamašita.

${ }^{7}$ Jamašita je osvajač brojnih medalja sa svetskih prvenstava i Olimpijskih igara. U Svetskoj džudo federaciji obavljao je funkcije vezane za edukaciju, a danas važi za jednog od najvećih džudista svih vremena.

8 „Radovan Stojičić““, Milicionar, 18. 5. 1992; „Naimenovanja u Ministarstvu unutrašnjih poslova Republike Srbije: Radovan Stojičić - zamenik ministra“, Milicionar, septembar 1993; „Ukaz predsednika Republike: Generali Ministarstva unutrašnjih poslova“, Milicionar, april 1996;
} 
Aktivan takmičarski život zahtevao je vreme. Rašović svedoči kako je morao stalno da moli njegove nadređene za odsustvo da bi učestvovao na takmičenjima. Milorad Vlahović, načelnik uprave za suzbijanje kriminaliteta MUP Srbije i Stojičićev kolega iz kluba, takođe navodi da u početku nisu imali puno razumevanja od rukovodstva i da su sami morali da uklapaju redovne treninge sa radom u smenama kao milicionari-pozornici. Uz Stojičića i Vlahovića, Stanko Lopatić, Zoran Dimitrijević, Ševćet Mašović i Zoran Simović svoju džudo karijeru započeli su u Sremskoj Kamenici da bi je nastavili u džudo klubu „Partizan“. Karijeru su ometale službene obaveze da bi konačno policija 1976. godine oformila svoj džudo klub „Milicionar“, u okviru istoimenog sportskog društva koje je iste godine obnovljeno. Stojičić je bio prvi i dugogodišnji trener i takmičar tog kluba. ${ }^{9}$

Kada je Stojičić sredinom 90-ih bio na najvišoj funkciji u policiji, aktivno je radio i na poboljšanju položaja džudo kluba „Milicionar“. Na svečanosti u Skupštini grada povodom 50 godina kluba uz osnivača tog sportskog društva, dr Dragana Petrovića, uručeno mu je priznanje kao najzaslužnijem članu, ,velikom sportisti, reprezentativcu Jugoslavije u džudou, čoveku koji je sa svojim saradnicima dao nemerljiv doprinos uspesima i razvoju SD „Milicionar“. Istom prilikom zlatnu plaketu kluba dobio je Rašović, tada sportski direktor Džudo saveza Jugoslavije. ${ }^{10}$ Sasvim sigurno s tim u vezi je otvaranje novog sportskog centra na Makišu 1994. godine iza kojeg je stajao ,veliki rad i entuzijazam zamenika ministra mr Radovana Stojičića“. ${ }^{11}$ Takođe, 1995. džudo klub „Milicionar" prvi put ulazi u saveznu ligu. ${ }^{12}$

Prvu značajniju policijsku funkciju Stojičić je dobio 1983. godine kao zamenik, potom i rukovodilac novooformljene Jedinice milicije za specijalna dejstva u MUP-u Republike Srbije. ${ }^{13}$ Kako Rašović svedoči, komandir te jedinice je u nedostatku adekvatnih kadrova upitao Rašovića za preporuku, a on mu je bez dvojbe preporučio Stojičića. Zajedno sa Rašovićem, nastojao je da poveća i održava na visokom nivou fizičku spremu pripadnika jedinice. Kada je komandir te jedinice prešao u administraciju, njegovu funkciju preuzima Stojičić. ${ }^{14}$

„Odlazak hrabrog i pravednog starešine“, Policajac, april 1997; Intervju autora članka sa Vukom Rašovićem, 10. 8. 2018.

9 Svetislav Jokić, Snežana Perišić, Dragana Kajganić, Vladan Čolić, Milanka Ivezić, Mirijana Manić, Nenad Milojević, Buda Radović, Milan Simić i Dragan Petrović, Više od sporta: Monografija povodom 50 godina SD „Milicionar “ (Beograd: Ministarstvo unutrašnjih poslova Republike Srbije, 1996), 100; „U društvu najboljih“, Milicionar, jul 1995.

${ }^{10}$ Intervju autora sa Vukom Rašovićem, 10. 8. 2018; „Intervju sa legendom srpskog džudoa: Bata Živojinović je najjači čovek koga sam upoznao, Milošević je imao impresivnu osobinu kakvu nigde nisam video“, Telegraf, 11. 11. 2017; „Svečana akademija povodom 50 godina postojanja SD „Milicionar“: Više od sporta“, Milicionar, maj 1996.

${ }^{11}$ S. Jokić i drugi, n. d., 19.

12 „U društvu najboljih“, Milicionar, jul 1995.

13 „Naimenovanja u Ministarstvu unutrašnjih poslova Republike Srbije: Radovan Stojičić - zamenik ministra", Milicionar, septembar 1993.

${ }^{14}$ Intervju autora sa Vukom Rašovićem, 10. 8. 2018. 
$\mathrm{Na}$ toj poziciji se istakao prilikom štrajka rudara u Trepči, u rudniku Stari trg, kada se sa svojim ljudima spustio u okno i rešio kriznu situaciju. ${ }^{15}$ Ubrzo, 1991. godine, unapređen je u komandanta specijalnih jedinica MUP-a Srbije. ${ }^{16}$ Iste godine nalazimo ga i na poziciji komandanta Teritorijalne odbrane Slavonije, Baranje i Zapadnog Srema, a ima navoda da je „stajao“ iza čitave bezbednosne strukture Istočne Slavonije i da je u centru za obuku u Erdutu sarađivao sa Željkom Ražnatovićem Arkanom. ${ }^{17}$ Sledeća preporuka išla je preko džudoa: posle demonstracija 1991. godine Rašović navodi da je Slobodan Milošević svog telohranitelja Sentu Milenkovića pitao za preporuku. Senta je predložio Stojičića i on preuzima funkciju načelnika Resora javne bezbednosti i 1993. godine funkciju zamenika ministra unutrašnjih poslova Republike Srbije. Stojičić je imao zadatak da reformiše policiju da bi sledeće izazove dočekala spremna budući da se prilikom demonstracija marta 1991. nije naročito pokazala, navodi Rašović. Kao načelnik, Stojičić je insistirao na disciplini i fizičkoj spremi i imao je bespogovoran autoritet. ${ }^{18}$

Kao zamenik ministra organizovao je 1994. godine prvo savetovanje iz specijalnog fizičkog obrazovanja, kojem su osim pripadnika Ministarstva unutrašnjih poslova prisustvovali sportski stručnjaci i zdravstveni radnici. Na otvaranju savetovanja, Stojičić je istakao: „Predstavnici MUP, Vojske Jugoslavije i sve ostale strukture koje se bave ovim poslom veliku pažnju poklanjaju specijalnom fizičkom osposobljavanju, jer samo zdrav i psihofizički sposoban čovek može da izvršava najsloženije zadatke. Ovo je vreme i mesto da vam kažem da su upravo zahvaljujući takvoj obuci naših ljudi, ovo Ministarstvo i njegovi pripadnici u najkritičnije vreme za Republiku Srbiju, sa visokom ocenom i rezultatima ostvarili sve svoje zadatke i na najtežim mestima čak i dali svoj život"، Savetovanje je značajno i iz ugla saradnje sa Fakultetom za fizičku kulturu u Beogradu (nekadašnji DIF, danas Fakultet sporta i fizičkog vaspitanja), gde je niz istaknutih profesora dao svoj doprinos u vidu 25 odabranih radova koji se bave fizičkom spremom pripadnika vojske i policije. ${ }^{19}$ Dve godine kasnije, povodom 50 godina sportskog društva „Milicionar“, na istoj liniji Stojičić ističe: „Sport je uvek bio u funkciji naše službe““. ${ }^{20}$

Stojičić se pominje i kao jedan od inicijatora osnivanja Policijske akademije. Najveći pečat, međutim, ostavio je u profesionalnom i psihofizičkom napretku pripadnika policije $\mathrm{i}$ taj aspekt je prvi istaknut prilikom njegove komemoracije. ${ }^{21}$

\footnotetext{
${ }^{15}$ Rudari albanske nacionalnosti stupili su u štrajk glađu 20. februara 1989. Štrajk je odmah doveden u vezu sa ukidanjem autonomije Kosova, a posle podrške štrajkačima iz Slovenije i iz Hrvatske dobio je jugoslovensku dimenziju pred sam raspad države.

${ }^{16}$ „Naimenovanja u Ministarstvu unutrašnjih poslova Republike Srbije: Radovan Stojičić - zamenik ministra“, Milicionar, septembar 1993.

${ }^{17}$ Policing and Internal Affairs in the Serb-Controlled Entities in Croatia 1990-1993, Christian Axboe Nielsen, Research report prepared for the case of HADŽIĆ (IT-04-75), 150, 207.

${ }^{18}$ Intervju autora sa Vukom Rašovićem, 10. 8. 2018.

19 „Uspelo savetovanje: Prvo savetovanje iz SFO“, Milicionar, novembar 1994.

${ }^{20}$ S. Jokić i drugi, n. $d ., 7$.

${ }^{21}$ „Odlazak hrabrog i pravednog starešine“, Policajac, april 1997.
} 
Policija je za vreme vladavine Slobodana Miloševića išla procesom militarizacije. To je bila posledica nepoverenja Miloševića prema vojsci i traženja oslonca u MUP-u, što je i dovelo do njegovog jačanja. Rašović navodi da je Stojičić u policiji uveo sistem rada sličan onom u vojsci i da je pooštrio disciplinu. ${ }^{22}$

Konačno, ukazom predsednika Republike u Ministarstvo unutrašnjih poslova postavljeni su generali. Najviši čin dodeljen je Stojičiću: general-pukovnik. ${ }^{23}$ Iz ličnog ugla, Rašović iznosi da se njegov odnos prema prijateljima sa džudoa dobijanjem visoke funkcije uopšte nije promenio, sa samim Rašovićem se pobratimio. ${ }^{24}$

Što se tiče Stojičićevog materijalnog položaja, koji se dovodi i u vezu sa švercom cigareta, ${ }^{25}$ Rašović navodi da se nije značajno promenio. Do tada je živeo u iznajmljenom stanu, potom je dobio stan 80-90 kvadrata i to je jedina značajna promena njegovog materijalnog stanja. Na useljenju je bio i Rašović i tom prilikom Stojičić mu je pokazao arsenal naoružanja u kome se nalazio i ručni bacač (bazuka). ${ }^{26}$

Ubijen je u atentatu 11. aprila 1997, po saopštenju MUP-a Republike Srbije „oko 00,30 sati u Beogradu, u ulici general Ždanova broj 70“. „Maskirani, nepoznati izvršilac prišao je stolu za kojim je sedeo Stojičić sa sinom i, sa više hitaca iz automatskog oružja, lišio ga života, a potom pobegao sa lica mesta“. Sahranjen je sutradan, 12. aprila u Aleji zaslužnih građana na Novom groblju u Beogradu, a na sahrani prvi je govorio Rašović: „Radovan Stojičić je bio ne samo dobar policajac, već i sjajan sportista, reprezentativac, osvajač medalja, sportski učitelj. Tragični i prerani odlazak Radovana Stojičića, šampiona, sportskog pedagoga i predsednika Džudo saveza Jugoslavije, predstavlja gubitak koji naša organizacija ne može nadoknaditi, a za nas njegove sportske drugove, nikada više neće biti isto, kao što je do sada bilo“. O značaju Rašovića i njegovoj bliskosti sa Stojičićem govori i podatak da je posle njega govornik bio general-major Obrad Stevanović u ime Ministarstva unutrašnjih poslova Republike Srbije. Deo oproštajnih govora bio je posvećen pečatu koji je džudo ostavio na biografiju Stojičića, i obrnuto: pečatu koji je Stojičić ostavio na jugoslovenski džudo. ${ }^{27}$

Za novog predsednika Džudo saveza Jugoslavije imenovan je generalmajor Staniša Trujić, koji je zajedno sa Rašovićem bio gost na prijemu kod Slobodana Miloševića. ${ }^{28}$ Prijem kod predsednika pokazatelj je značaja koji je

\footnotetext{
22 Intervju autora sa Vukom Rašovićem, 10. 8. 2018.

23 „Ukaz predsednika Republike: Generali Ministarstva unutrašnjih poslova“, Milicionar, april 1996.

${ }^{24}$ Intervju autora sa Vukom Rašovićem, 10. 8. 2018; „Intervju sa legendom srpskog džudoa: Bata Živojinović je najjači čovek koga sam upoznao, Milošević je imao impresivnu osobinu kakvu nigde nisam video“, Telegraf, 11. 11. 2017.

${ }^{25}$ Šverc cigareta koji je 90-ih godina u Jugoslaviji poprimio endemske razmere često se dovodi u vezu sa Stojičićem, pa i njegovo ubistvo u atentatu 1997. godine. Tadašnji načelnik SUP-a Beograda Branko Đurica na pitanje ko je ubio Badžu, izjavio je: „Evo, ubile su ga cigarete“. Ipak, svi navodi su na nivou spekulacija i Stojičićeva veza sa švercom cigareta ostaje tek da se dokaže. „Politička ekonomija cigareta - Markova posla i prijatelji“, Vreme, mart 2006.

${ }^{26}$ Intervju autora sa Vukom Rašovićem, 10. 8. 2018.

27 „Odlazak hrabrog i pravednog starešine“, Policajac, april 1997; Intervju autora sa Vukom Rašovićem, 10. 8. 2018.

${ }^{28}$ „Lepši dani za jugoslovenski džudo“, Policajac, jun 1997.
} 
Milošević pridavao džudou i dobre saradnje Džudo saveza Jugoslavije sa policijom, koju je nastojao da očuva i posle ubistva Stojičića.

Stojičićev napredak bio je duboko vezan za džudo. Takmičar od malena, kompletan džudista, sa istom dinamikom nastavio je da trenira i da se takmiči i po zaposlenju u policiji. Dalji napredak kroz policijsku hijerarhiju duboko je vezan za džudo gde je do najvišeg mesta došao preporukom, iza koje su stajali poznanstvo sa strunjače i kredibilitet izgrađen na njoj.

\section{Senta Milenković}

Svoje prve džudo korake Milenković je načinio u Smederevu. Uz Milenka Kresoja, još kao mladića primetio ga je Rašović i redovno trenirao. Milenković je završio Srednju školu unutrašnjih poslova i Višu kriminalističku školu u Zemunu i radio kao pripadnik specijalne (antiterorističke) jedinice milicije. Kolega iz jedinice bio mu je stari poznanik sa strunjače i iz Srednje škole unutrašnjih poslova - Radovan Stojičić Badža. Potom, postao je prvi čovek obezbeđenja Slobodana Miloševića, po čemu je i najpoznatiji. U toku te službe završio je Defektološki fakultet u Beogradu na kome je i magistrirao, pri čemu ima navoda da je koristio položaj kako bi lakše položio ispite. U čin general-majora promovisan je 1997. godine. ${ }^{29}$

Iako je obavljao značajnu funkciju, Milenkovićev odnos prema prijateljima sa džudoa se nije izmenio. Sa Stojičićem, osim službene saradnje, delio je decenije zajedničkog bavljenja džudoom. Kao već stariji, sretali su se na strunjači džudo kluba „Milicionar" gde je Senta ubrajan među ,asove“ tog kluba. ${ }^{30}$ Poučen tim iskustvom Senta je preporučio Stojičića Miloševiću kao kadar za načelnika Službe javne bezbednosti. ${ }^{31}$

Po svedočenju počasnog predsednika Socijalističke partije Srbije i njegovog bliskog prijatelja Milutina Mrkonjića, vežbao je predano do kraja života. ${ }^{32}$ Preminuo je 2016. godine. ${ }^{33}$

\section{Goran Radosavljević Guri}

Goran Radosavljević Guri je u policiju ušao preko sporta. Kao diplomac Fakulteta sporta i fizičkog vaspitanja radni odnos zasnovao je 1986. godine kao instruktor posebne policijske obuke u Sekretarijatu u Beogradu. Sredinom 90 -ih bio je jedan od zamenika komandanta Posebne jedinice policije. ${ }^{34}$

\footnotetext{
${ }^{29}$ Intervju autora sa Vukom Rašovićem, 10. 8. 2018; „Kako sam trenirao Badžu, Sentu i Gurija“, Večernje novosti, 13. 8. 2017; „General i vojvoda“, Vreme, 5. 4. 2001; „Preminuo Senta Milenković, Miloševićev telohranitelj“, Politika, 28. 2. 2016; „Zvezdica bez lica“, NIN, 11. 7. 1997.

30 „U društvu najboljih“, Milicionar, jul 1995; S. Jokić, i drugi, n. d., 102.

${ }^{31}$ Intervju autora sa Vukom Rašovićem, 10. 8. 2018.

32 „Senta je bio ljudina i veliki profesionalac! Mrkonjić otvorio dušu i ispričao sve o čuvenoj Slobinoj senki“, Telegraf, 1. 3. 2016.

33 „Preminuo Senta Milenković, Miloševićev telohranitelj“, Politika, 28. 2. 2016.

34 „Najviše i najuglednije priznanje - nagradu „Radovan Stojičićc primila tri pripadnika Ministarstva unutrašnjih poslova“, Policajac, maj 1998.
} 
Rašović ga je upoznao u sali Vatrogasnog doma, ali nije imao bliske odnose s njim kao sa Milenkovićem i Stojičićem. Budući da Guri nije bio takmičar, Rašović nije imao priliku da kao direktor Džudo saveza Jugoslavije vodi računa o njegovoj takmičarskoj karijeri. Kao profesor fizičkog vaspitanja koji je diplomirao na temi iz džudoa, Guri je odabrao više naučni pristup. ${ }^{35}$

Primećen je 1994. godine kada je od ministra unutrašnjih poslova kao nagradu za postignute rezultate dobio pištolj. ${ }^{36}$ Džudom je nastavio da se bavi, naročito u klubu „Milicionar“ gde je 1993. postao član Izvršnog odbora celog sportskog društva. ${ }^{37}$ Potom, džudo klub transformiše $u$ „Žandarmeriju“, pod kojim imenom postoji i danas. ${ }^{38}$

U odnosu prema policiji, Guri i Stojičić imali su zajedničku crtu: insistirali su na dobroj fizičkoj spremi policajaca. „Najviše i najuglednije“ priznanje koje je uspostavljeno ubrzo posle ubistva Stojičića, nagradu „Radovan Stojičićc“, 1998. godine dobila su tri pripadnika Ministarstva unutrašnjih poslova, među kojima je bio tada major Goran Radosavljević. ${ }^{39}$ Kao borac istakao se tokom rata na Kosovu i stekao svoj prepoznatljiv nadimak: Guri (,guri“ - „kameni“ na albanskom jeziku). Pored ratničke slave u odnosima prema prijateljima, po svedočenju Rašovića, zadržao je prisnost i jednostavnost. ${ }^{40}$

\section{Drugi istaknuti džudisti u politici 90-ih}

Zajedno sa Sentom Milenkovićem u Smederevu je trenirao Marinko Kresoja. Mladić iz Bosanskog Petrovca završio je Srednju školu unutrašnjih poslova u Kamenici, a zatim i Fakultet bezbednosti. Karijeru je započeo kao milicionar-pozornik, da bi napredovao preko načelnika odeljenja unutrašnjih poslova do pomoćnika načelnika Resora javne bezbednosti. ${ }^{41}$ Još kao mladog džudistu primetio ga je Rašović i od malena trenirao i pratio njegov razvoj u kompletnog takmičara. ${ }^{42}$

Kresoja je u karijeri došao do pomoćnika načelnika Resora javne bezbednosti MUP sa činom general-majora, ali nije zapostavio treninge i prijateljstvo sa Rašovićem. Obavljao je i funkciju predsednika džudo kluba „Milicio-

\footnotetext{
${ }^{35}$ Intervju autora sa Vukom Rašovićem, 10. 8. 2018; „Kako sam trenirao Badžu, Sentu i Gurija“, Večernje novosti, 13. 8. 2017.

${ }^{36}$ „Najviše i najuglednije priznanje - nagradu „Radovan Stojičićc primila tri pripadnika Ministarstva unutrašnjih poslova“, Policajac, maj 1998.

37 „Novi Izvršni odbor Sportskog društva „Milicionar“““, Milicionar, januar 1993.

${ }^{38}$ Intervju autora sa Vukom Rašovićem, 10. 8. 2018.

${ }^{39}$ Isto; „Najviše i najuglednije priznanje - nagradu „Radovan Stojičić“ primila tri pripadnika Ministarstva unutrašnjih poslova“, Policajac, maj 1998.

${ }^{40}$ Intervju autora sa Vukom Rašovićem, 10. 8. 2018.

41 „Ukaz predsednika Republike: Generali Ministarstva unutrašnjih poslova“, Milicionar, april 1996.

42 Intervju sa Vukom Rašovićem, 10. 8. 2018; „Kako sam trenirao Badžu, Sentu i Gurija“, Večernje novosti, 13. 8. 2017; ,Intervju sa legendom srpskog džudoa: Bata Živojinović je najjači čovek koga sam upoznao, Milošević je imao impresivnu osobinu kakvu nigde nisam video", Telegraf, 11. 11. 2017.
} 
nar“. Iako na visokoj poziciji, materijalno stanje mu se neznatno promenilo: verovatno preterano, ali ilustrativno, Rašović navodi da mu je porodica doručkovala čaj i hleb. Kao takav uživao je veliko poštovanje i posle petooktobarskih promena. Kada ga je nova vlast pozvala da zadrži funkciju, izjavio je: „Pa, ljudi, ja sam vas hapsio. Šta ću ja sa vama?"“, svedoči Rašović. ${ }^{43}$

U Srbiji su se kao obezbeđenje političara isticali i džudisti Zvonko Osmajlić i Boban Petković. Prvi je štitio Vuka Draškovića, a drugi Vojislava Šešelja. $^{44}$

Rašović se seća i džudista koji su potekli sa iste strunjače, ali su završili na drugim stranama tokom ratova 90-ih. Tako je Hajlurah Trnava, kompletni džudista i učenik Srednje škole unutrašnjih poslova, sa Rašovićem imao nekoliko mečeva 70-ih u Prištini. U turbulentnoj 1998/99. borio se na strani OVK i istakao kao jedan od značajnijih boraca. ${ }^{45}$

U Republici Srpskoj takođe su bila dvojica istaknutih džudista: Momčilo Mandić i Mićo Stanišić. Mandić je bio uspešan takmičar, osvajač državne medalje, a u vladi Republike Srpske obavljao je funkciju ministra pravde. Stanišić, takođe istaknuti džudista, bio je ministar unutrašnjih poslova Republike Srpske. Za razliku od ostalih ovde navedenih, obojica nisu potekli iz Srednje škole unutrašnjih poslova već su u policiju ušli kao pravnici i džudisti. Isključivo takmičarsku biografiju imao je Rajko Kušić, učesnik Olimpijskih igara u Moskvi 1980. godine, koji je u ratu imao istaknutu ulogu u Vojsci Republike Srpske i zbog tih zasluga odlikovan Karađorđevom zvezdom II reda. Pred sam kraj rata poginuo je u saobraćajnoj nesreći. ${ }^{46}$ Slično kao u Jugoslaviji, u Republici Srpskoj postojao je džudo klub „Policajac“, u bliskoj vezi sa MUP-om. ${ }^{47}$

U Hrvatskoj se isticao Josip Lucić, kompletni džudista i diplomac Kineziološkog fakulteta Sveučilišta u Zagrebu. Sa Rašovićem je sarađivao u zajedničkoj misiji da unaprede jugoslovenski džudo. Rašović navodi da im je jednom prilikom poklonio trenerke. Po izbijanju rata te veze se prekidaju i Lucić preuzima funkcije u okviru hrvatske vojske: od instruktora do pomoćnika načelnika Generalštaba kopnene vojske. Preko dužnosti pomoćnika ministra Ministarstva obrane Republike Hrvatske dogurao je do samog vrha: bio je načelnik Generalštaba i prvi na dužnosti dva mandata: od 2003. do 2011. godine.

Odličan džudista bio je Mladen Markač, za koga Rašović navodi da su bili retki oni koji su uspeli da ga bace na strunjači. ${ }^{48}$ Po izbijanju rata, bio je jedan od ključnih figura oko Franje Tuđmana kao pomoćnik ministra policije i

\footnotetext{
${ }^{43}$ Intervju autora sa Vukom Rašovićem, 10. 8. 2018; „Kako sam trenirao Badžu, Sentu i Gurija“, Večernje novosti, 13. 8. 2017.

${ }^{44}$ Intervju autora sa Vukom Rašovićem, 10. 8. 2018; „Poslednji samuraj na Balkanu“, Vesti online, 17. 5. 2013.

${ }^{45}$ Intervju autora sa Vukom Rašovićem, 10. 8. 2018.

${ }^{46}$ Isto.

${ }^{47}$ „Pobednik kupa RS“, Policajac: list Ministarstva unutrašnjih poslova Republike Srpske, februar 1997; „Osam medalja za najmlađe“, Policajac: list Ministarstva unutrašnjih poslova Republike Srpske, april 1997.

${ }^{48}$ Intervju autora sa Vukom Rašovićem, 10. 8. 2018.
} 
komandant specijalne policije. Bio je jedan od ključnih aktera operacije „Oluja“ i ubrzo je unapređen u čin general-pukovnika. Uz Antu Gotovinu i Ivana Čermaka optužen je u Haškom tribunalu za ratne zločine, ali je oslobođen svih optužbi 2012. godine i pušten na slobodu.

\section{Zaključak: Savršeni kadrovi za burna vremena?}

Zajednička determinanta za sve navedene aktere ratova 90 -ih godina prošlog veka bio je džudo. Na strunjaču su stupili u najranijem dobu i sa nje nisu sišli sve do preuzimanja visokih funkcija, neki od njih ni tada. Većina njih potekla je iz siromašnih porodica i svoje ime izgradili su preko džudoa. Najbolji primer je karijera Sente Milenkovića i pozicija da on predloži Slobodanu Miloševiću za direktora policije Radovana Stojičića Badžu. Do telohranitelja predsednika Milenković je došao preko džudoa i sa te pozicije, opet preko džudoa, preporučuje Stojičića kome je jedini kredibilitet bio opet samo džudo. U svemu tome istaknutu ulogu imao je džudo klub „Milicionar“. Pozicija i značaj džudoa u okviru policije omogućila im je karijerno napredovanje, ali i čitavu mrežu neformalnih veza koja se pokazala itekako značajna za to napredovanje. ${ }^{49}$

Iako su svi potekli mahom sa iste strunjače, neretko trenirali i takmičili se zajedno, po izbijanju ratova našli su se na suprotstavljenim stranama. Ono što im je svima zajedničko jeste da su dospeli do najviših vojnih i policijskih pozicija. Rašović odgovor nalazi u prirodi džudoa: „Džudo je u suštini proces donošenja odluka. Ti moraš da doneseš odluku jer imaš meč sa čovekom koji je tvoj rimejk. Znači, loviš lovca. To je partija šaha, ali i telom i umom. Tvoje ruke su senzori i antene koje ti prenose njegove namere i njegove kvalitete, a tvoje ruke to daju njemu. To je obrada podataka, jedan neverovatno živ proces koji mogu da znaju samo ljudi koji u tome učestvuju, u kome se donose odluke i ako ti imaš, kao što su oni imali, na desetine, na stotine mečeva to postane deo tebe “. ${ }^{50} \mathrm{~S}$ druge strane, ove veštine upotrebljavane su sa najviših policijskih funkcija, a stečene kroz bavljenje borilačkom veštinom sa istančanom i kompleksnom etikom. Ostaje otvoreno pitanje: U kojoj meri je etika džudoa kompatibilna sa ovim profesijama?

Ovako sagledane uloge istaknutih džudista tokom ratova 90-ih godina obaraju sam pojam ,džudo klan“. Kada se bivši prijatelji sa strunjače posmatraju preko nišana, o bilo kakvim klanovima ne može biti govora. Ako bi se za

\footnotetext{
${ }^{49} \mathrm{Na}$ sličnim pozicijama stajao je i karate gde su se takođe istaknuti karatisti odlično etablirali u policijskim strukturama. Zanimljivo, u odnosu sa džudistima su bili rezervisani ili kako navodi karatista Vitomir Žepinić na suđenju Mići Stanišiću i Stojanu Župljaninu: „To su dva sporta i nikad se nismo voleli. Bio je sukob sve vreme“. Eventualno postojanje i pozicija karate klana ostaje tema za buduća istraživanja naročito uzimajući u obzir da se u istom periodu 90-tih na sličan način neformalna grupacija džudista, boksera i rvača formirala i u Rusiji oko Lenjingradskog Instituta za fizičku kulturu. International Criminal Tribunal for the former Yugoslavia, 100128IT, pg. 5689, https://www.icty.org/x/cases/zupljanin_stanisicm/trans/en/100128IT.htm;Vadim Volkov, Violent Entrepreneurs: The Use of Force in the Making of Russian Capitalism (Ithaca and London: Cornell University Press, 2002), 10, 102.

${ }^{50}$ Intervju autora sa Vukom Rašovićem 10.08.2018.
} 
istaknutu „srpsku“ ili ,jugoslovensku“ osovinu (Stojičić, Milenković, Radosavljević) taj termin i mogao upotrebiti, postavlja se pitanje zašto deo klana nisu bili i njihovi pandani u Hrvatskoj ili na prostoru Kosova? Takođe, da bi se realno sagledala važnost, ali i ograničenja veza stvorenih ovom zajedničkom sportskom aktivnošću, treba imati u vidu i niz drugih istaknutih vojnih i policijskih funkcionera koji nisu potekli sa strunjače a međusobno su blisko sarađivali.

\section{REFERENCE}

- Helmke Gretchen, and Steven Levitsky. ,Informal Institutions and Comparative Politics: A Research Agenda“. Perspectives on Politics, vol. 2, no. 4, (2004), 725-740. https://doi.org/10.1017/S1537592704040472

- Informal Power Networks, Political Patronage and Clientelism in Serbia and Kosovo*. Edited by Slobodan Cvejić. Belgrade: SeConS, 2016.

- International Criminal Tribunal for the former Yugoslavia, 100128IT, pg. 5689, https://www.icty.org/x/cases/zupljanin_stanisicm/trans/en/100128IT.htm

- Jokić Svetislav, Snežana Perišić, Dragana Kajganić, Vladan Čolić, Milanka Ivezić, Mirijana Manić, Nenad Milojević, Buda Radović, Milan Simić, i Dragan Petrović. Više od sporta: Monografija povodom 50 godina SD , Milicionar". Beograd: Ministarstvo unutrašnjih poslova Republike Srbije, 1996.

- Nedeljković, Stojan V. Džudo u Jugoslaviji 1955-2005. Beograd: Stojan Nedeljković, 2007.

- Policing and Internal Affairs in the Serb-Controlled Entities in Croatia 19901993, Christian Axboe Nielsen, Research report prepared for the case of HADŽIĆ (IT-04-75).

- Volkov, Vadim. Violent Entrepreneurs: The Use of Force in the Making of Russian Capitalism. Ithaca and London: Cornell University Press, 2002. 
NIKOLA MIJATOV, PhD, Research Associate

Institute for Contemporary History

Belgrade, Republic of Serbia

nikolamijatov@gmail.com

\section{JUDO CLAN: THE ROLE OF JUDO IN THE CAREERS OF PROMINENT POLICE OFFICIALS OF YUGOSLAVIA}

\section{Summary}

"Judo clan" is the term often affiliated with prominent members of the police forces during the regime of Slobodan Milošević. Radovan Stojičić Badža, Senta Milenković, and Goran Radosavljević Guri rose to prominence and achieved high positions in the Serbian Police thanks to judo. Stojičić was the deputy minister of internal affairs, Milenković was President Milošević's first bodyguard, and Radosavljević was a distingusihed police officer and later first commander of the Gendarmery. They all had a judo background and were members and officials of the "Milicionar" judo club. In Vojvodina, Marinko Kresoje stood out as the assistant chief of the department of public security. Furthermore, there were also many prominent judokas that had trained and competed together in socialist Yugoslavia but were on opposite sides in the war. In Republika Srpska there was Momčilo Mandić, Mićo Stanišić, and Rajko Kušić. In Croatia there was Mladen Markač and Josip Lucić. Hajlurah Trnava was a prominent judoka in the area of Kosovo. Given the fact that they were all distinguished masters and champions of judo and tatami buddies up until the war, the term "Judo clan" is not quite accurate. While it can denote only "Yugoslav" or "Serbian" judokas who were close associates of Slobodan Milošević, there is no reason to exclude their judo colleagues from the Republika Srpska, Croatia, and from the area of Kosovo. Still, the subsequent careers of all of these judokas show the close connection that this sport had with both the police and the military in Yugoslavia and in the states that emerged from its breakup.

KEYWORDS: Judo, Judo Clan, Radovan Stojičić Badža, Senta Milenković, Goran Radosavljević Guri 